\title{
The Role of Transport System in Rural Development: A Case Study of Ehime Mbano Local Government Area of Imo State Nigeria
}

\author{
Sylvanus Iro* \\ Department of Geography, Imo State University, Nigeria
}

\begin{abstract}
This study was conducted to examine the role of transport system in rural development in Ehime Mbano L.G.A of Imo State. It has been observed that untarred/seasonal roads and foot track dominates in the study area. Lack of good roads in the study area has great negative impacts on the socio-economic activities of the rural communities. The observations of the area show that transport system has been faced with numerous problems due to poor road maintenance and bad road, lack of fund to construct good roads and poor road network. A total of 500 questionnaires were administered to the respondents in the selected areas of Ehime Mbano L.G. A of Imo State. The hypothesis formulated was tested using Chi-Square techniques. The result implies that the provision of transport services in rural areas is to a large extent satisfactory. Also, the result of the findings indicates that transport system has a significant impact on rural development in Ehime Mbano Local Government Area of Imo State. The findings equally, reveal that transport system has played significant role in the development of Ehime Mbano Local Government Area of Imo State. The study concluded that there is a significant relationship between the causes of road accident on urban/rural road and the problems of transport system in Ehime Mbano Local Government Area of Imo State. The study recommended that the government and private organizations should organize public awareness programs on the dangers of inexperience driving alongside the positive role of transport system on rural development.
\end{abstract}

\section{Introduction}

Transport is seen as a necessary ingredient in all aspects of socioeconomic development. It plays a key role in getting land into production, in marketing agricultural commodities and in the development of industries, in the expansion of ideas. ${ }^{1}$ Highlighted the similarities between rural transportation and rural development and noted that no society can exist above subsistence level without a measure of improvement in its transport system.

The concept of rural development has received good publicity and attention in recent years in development literature. ${ }^{2}$ It is on the recommendation list of development planners as an elixir that can ignite the overall development of a region. The placement of emphasis on rural development by policy makers and development planners stems from the realization that rural areas are pivotal to national and regional development. This is by virtue of the abundance of primary products, especially agricultural products like cocoa, timber, coffee, palm oil, rubber etc. in the rural sector. It is common knowledge that these primary products are the foremost ingredients of industrial processes in the urban sector. ${ }^{3,4}$

Rural development has profited from a plethora of definitions. One of such definitions is the one by Mabogunje ${ }^{5}$ who states that rural development has to do with the improvement of the standards of living of the low-income population living in rural areas on a self-sustaining basis through transforming the socio-spatial structures of the capacity of individuals to actualize their inert potentials. In this way, rural development assists individuals in adapting effectively to the vicissitudes of their lives and their environment. ${ }^{6}$

\begin{tabular}{|l|l|}
\hline Quick Response Code: & $\begin{array}{l}\text { *Corresponding author: Sylvanus Iro, Department of Geography, Imo State University, Ower- } \\
\text { ri, Southern Nigeria } \\
\text { Received: 03 August, } 2021 \\
\text { Citation: Sylvanus Iro. The Role of Transport System in Rural Development: A Case Study } \\
\text { of Ehime Mbano Local Government Area of Imo State Nigeria. Glob Scient Res Env Sci. } \\
\text { 2021;1(4):1-10. DOI: 10.53902/GSRES.2021.01.000517 }\end{array}$ \\
\hline
\end{tabular}


It also assists in facilitating rural resources productivity with a view to enhancing rural income, increasing employment opportunities, and upgrading rural communities. ${ }^{7}$ Coombs and Ahmed ${ }^{8,9}$ envisioned rural development from a more holistic perspective and saw it as obliterator of the evil trinity of poverty, disease, and Ignorance. There is a noticeable relationship between accessibility, marketing, and agricultural development. ${ }^{10}$ An efficient transport is critically important to efficient agricultural marketing. When transport services are infrequent. Of poor quality or expensive, farmers will ineluctably sell their crops with grave difficulty. The similarities are also dissembled from the point of view that season impassable roads and slow or irregular transport services can lead to losses in the agricultural sector. ${ }^{11}$ Furthermore; the transport operating costs are higher on rough roads than on good quality roads. This also has implication on passenger fares and freight especially in moving agricultural produce from rural farm gates to urban markets. ${ }^{12}$ This may be applicable to Ehime Mbano Local Government Area of Imo State especially the rural.

\section{Statement of Problem}

Lack of good motorable roads in many rural areas in Nigeria has been the main "hindrance of rapid development". ${ }^{13}$ Rural residents need to receive essential social services such as medical care, going to work, buying, and selling goods at the market, attending school, event and accessing many other services just as their urban counterparts. However, frequent accessibility is restricted or limited because of the distance to those services. Even when transportation is available, the transport network is in bed condition. This affects maximum exploitation of Natural Resources, expansion of trade between communities, neglect on development of human resources which all result in isolation and underdevelopment of the rural areas. ${ }^{14}$ Todaro viewed development as a multi-dimensional process involving change in structural, habitual attitude and institutional as well as acceleration of economic growth. The emergence of modern means of transportation in the world and most importantly in developing countries like Nigeria has a remarkable influence on the socio-economic development of rural areas. Transportation to some in the urban settings is a choice not a concern. ${ }^{13}$ However; in rural setting the availability of transportation is often limited if provided at all. Motorized transport costs are usually very high during rainy season because of poor roads and incessant breakdown of vehicles. As Adeniji ${ }^{15}$ noted, the ability of agricultural and forest freight to absorb motorized transport costs varies according to the purpose and type of agricultural concerns are found to be more able to absorb public transport costs than the subsistence primary produces in the rural areas. As a result, a sizeable number of rural dwellers resort to head porterage, bicycles, land-draw carts, pick up vans and other forms of adapted or informed transport modes such as "to-fro" in Ehime Mbano Local Government Area of Imo State in particular and Nigeria in general. Therefore, the study intends to address the problems which affect transportation system and rural development. ${ }^{16}$

\section{Research Hypothesis}

The following null hypothesis will be tested in this study.

i. Transport system has no significant impact on rural development in Ehime Mbano Local Government Area of Imo State.

ii. Transport system has not played any significant role in the development in Ehime Mbano Local Government Area of Imo State.

\section{Methodology}

\section{Population of the study}

The population of the study will consist of the entire inhabitants of the various communities (Umuezeala Owerri in particular) that make up the study area. They are purposely chosen because they have good drainage system and transport system. The estimated number of populations of the towns and villages that make up the study area is about 169, 398 people (National Population Commission 2006).

\section{Sampling procedure}

The researcher cannot reach the entire Ehime Mbano Kingdom and that the entire Ehime Mbano Local Government Area cannot be given questionnaire, rather a systematic sampling technique was used to select villages/respondents. These villages are Umueze (Umueze I and II), Agbaja/Umukabia, Akanu/Umuezeala (Umunakanu and Umuezeala), Umualumaka /Umuihim, Nnato Ugwumezi (Umunumo and Nzerem/Ikpem), Nsu (Ikpa Nsu, Ihitte Nsu, Umuakagu Nsu and Umuezeala Nsu. One hundred and fifty-six (156) questionnaires were administered, that is thirteen (13) copies will be administered to each village. Here every first twenty fifth $\left(25^{\text {th }}\right)$ building from the selected rural villages was considered and the first household head is given the questionnaire. The table below shows the distribution of the questionnaire in the study area.

\section{Method of data analysis}

The statistical procedure for the analysis of data collected through the questionnaire is the Likert scale rating procedure in which percentage will be adequately used to express relative responses to all questions asked. Data collected for this study will be coded and compacted into manageable size. Tables and chart will be used to show frequencies of responses to questions. Verification of the major hypothesis of the study forms later part of this work and it has the advantage of emphasizing the level of significance or the probability that a given hypothesis is valid. In verification the following statistical test would be applied. 


\section{Data presentation and analysis}

A total of 520 questionnaires were administered by hand to the respondents in the study area and 500 copies were retrieved in an interval of two (2) weeks after administration. The questionnaires retrieved were collated and are presented in tables, graphs, and percentages. The information obtained from the field through the aid of research questionnaire are analyzed below using statistical diagrams such as tables, graphs, and percentages.

\section{Personal information of respondents}

Table 1 show that about $35 \%$ of the respondents are male while $65 \%$ are females who live in urban and rural areas of the study areas. This implies that more female attended to the questions raised. This is an indication that the female is more oriented about the role of transport system on rural development. They have better knowledge and understanding about the study. It could also be deduced that the females are more exposed to transportation issues than the male especially on how it affects rural development.

Table 1: Reasons why respondents prefer the route.

\begin{tabular}{|l|l|l|}
\hline Reason & Frequency & Percentages (\%) \\
\hline Its short & 285 & 57 \\
\hline No traffic delay & 80 & 16 \\
\hline Driver's decision & 100 & 20 \\
\hline No other route & 35 & 7 \\
\hline Total & $\mathbf{5 0 0}$ & $\mathbf{1 0 0}$ \\
\hline
\end{tabular}

Source: Fieldwork, 2018.

Figure 1 shows that $24 \%$ of the respondents are between the age of $16-20$ years, $15 \%$ are $21-30$ years of age, $36 \%$ are $31-40$ years of age, $13 \%$ are $41-50$ years of age and $12 \%$ are 50 years and above. This means that the population consists of adults and productive youths who have knowledge about the role of transport system in rural development in the study area. This is an indication that the impact of transportation network on rural development can best be explained by the middle age group (Figure1).

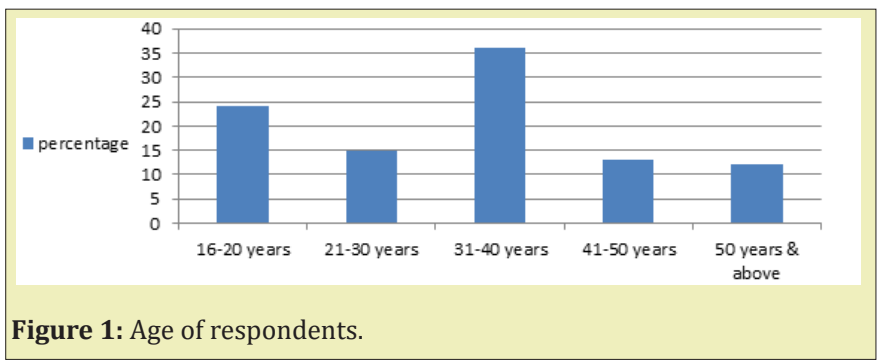

Figure 2 reveals that $27 \%$ of the respondents are students, $10 \%$ are self-employed workers, $25 \%$ are traders, $33 \%$ are civil servants, and $5 \%$ engage in other occupation such as transporters, those retired from the civil service, etc. This implies that the population of the study area comprise mainly of traders who engage in various trading activities which involves the use of vehicles and transportation service especially transporting goods from the rural areas to the urban centers. This indicates that transport system plays key role in the development of rural areas.

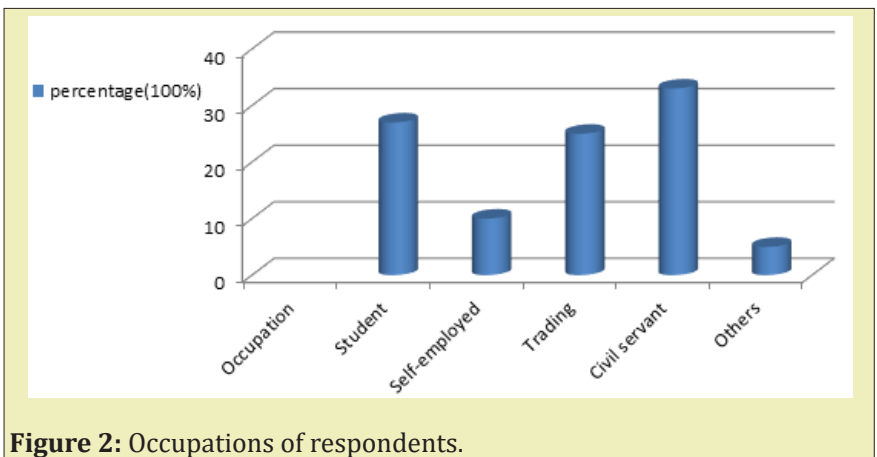

Figure 3 reveals that $3 \%$ of the respondents have no formal education, $7 \%$ have primary education, $23 \%$ have secondary education, 25\% are NCE/ND holders, 29\% are HND/B.Sc graduates, and $12 \%$ are M.Sc./Ph.D. holders. This means that most of the respondents are degree holders who can read and write and who have basic knowledge on the role of transport system on rural development in the study area.

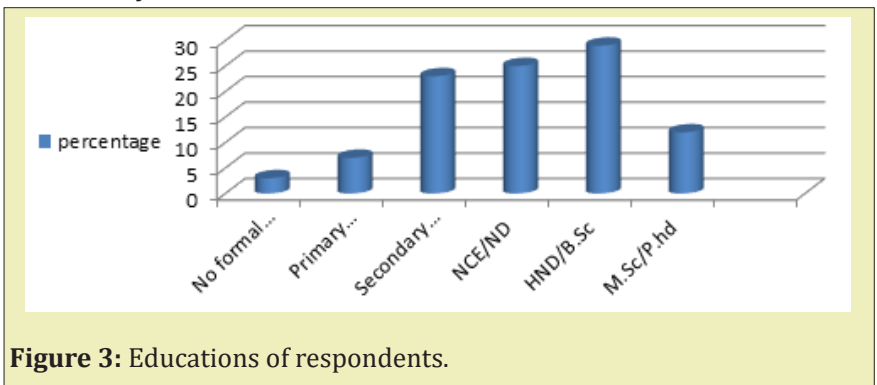

The role of transport system on rural development

Figure 4 the location/residence of the respondents in the study area. From the table above, it could be deduced that about $35 \%$ of the respondents reside in urban areas, 38\% live in rural areas, $23 \%$ live in remote villages and $3 \%$ live in nearby/neighboring community. This implies that majority of the respondents in the study area are mostly urban and rural dwellers who benefit from the rural development programs offered by the government especially in the aspect of transportation system.

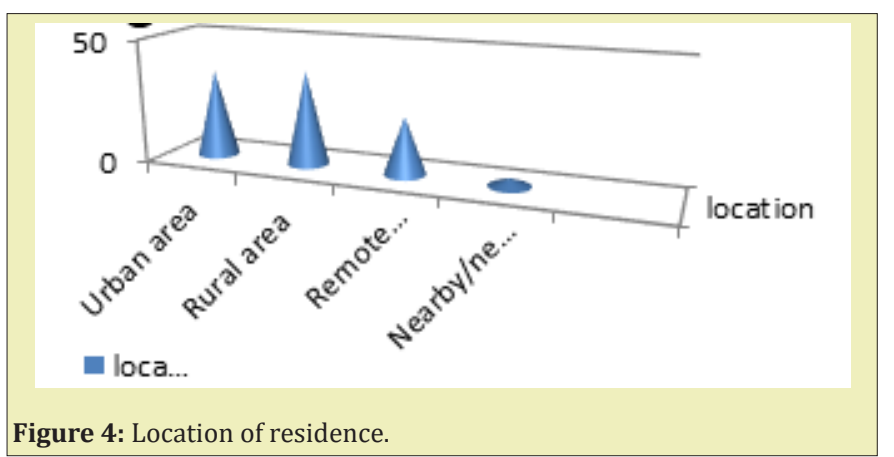

Figure 5 shows the route the respondents ply to their various destinations. It could be deduced that $31 \%$ use the major road, $25 \%$ 
take minor road, $12 \%$ take footpath, $20 \%$ take portage and $13 \%$ use other route such as water and rail transport (if any is available). This implies that most of the respondents ply the major road to their place of work/school/market/church/hospital.

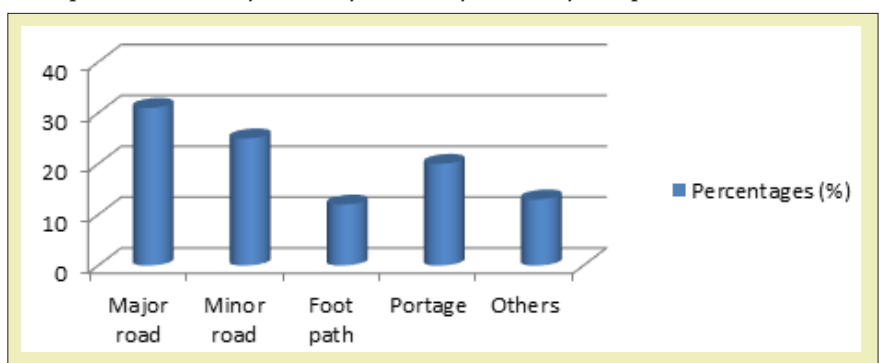

Figure 5: Route the respondents take to their various destinations.

Table 1 reveals that $57 \%$ of the respondents ply the route because it is shorter, $16 \%$ ply the route because there is no traffic delay, $20 \%$ ply the route because it is the driver's decision to use the route and $7 \%$ mentioned other reasons why they ply the route. This implies that majority of the respondents ply the route to their various destinations because it is shorter.

Figure 6 shows that $31 \%$ of the respondents use private car as their major means of transport, 5\% said commercial vehicles, 3\% said on foot, $42 \%$ said motorcycle/tricycle, $5 \%$ said bus/taxi and $14 \%$ mentioned other means of transport in the area. This implies that motorcycle and tricycle is the most important and common means of transport in the area.

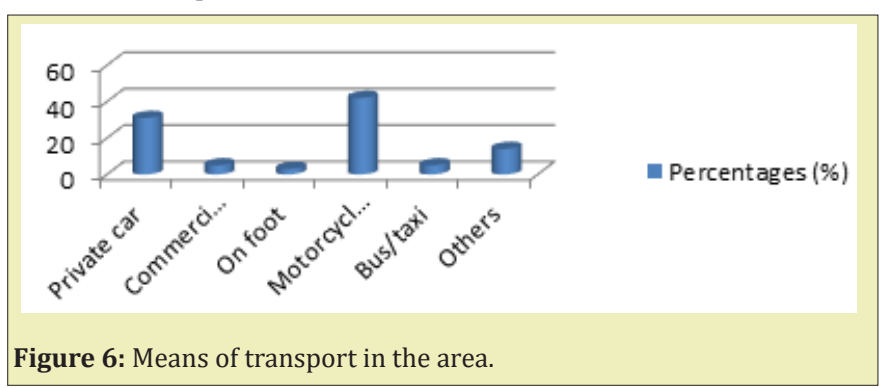

Figure 7 shows that $25 \%$ of the respondents indicated that bad $\mathrm{road} /$ potholes are the major causes of road accident on urban and rural roads in the area, $24 \%$ said over speeding, $15 \%$ said carelessness on the part of the driver, $17 \%$ said poor vehicle maintenance, $13 \%$ said drunk driving and hard drug and 5\% mentioned other causes such as poor traffic system, inexperience driving, pressure from passengers for driver to drive faster so as to meet up with appointments and emotional trauma. This implies that road accident is mainly caused by bad road/pothole, driver's carelessness, over speeding, poor vehicle maintenance and drunk driving/hard drug to also include inexperience driving.

Table 2 shows the causes of road accidents and its effect on transport system in rural areas. Item (a) shows that $65 \%$ of the respondents indicated that bad road has a very severe effect on transport system in the study area, $3 \%$ said severe, $21 \%$ said mild, $8 \%$ said not severe and $2 \%$ said no effect. This implies that bad road as a major cause of road accident affects transport system in rural areas. Item (b) shows that $29 \%$ of the respondents affirm that over speeding has a very severe effect on transport system in the area, $25 \%$ said severe, $23 \%$ said mild, $17 \%$ said not severe and $5 \%$ said no effect. This means that over speeding as a major cause of road accident affects transport system in rural areas. Item (c) shows that $39 \%$ of the respondents indicated that careless and inexperience driving has a very severe effect on transport system in the study area, $22 \%$ said severe, $19 \%$ said mild, $9 \%$ said the effect is not severe and $13 \%$ said not affected. This means that careless driving as a major cause of road accident affects transport system in rural areas (Figure 8). Item (d) reveals that $25 \%$ of the respondents were of the view that poor road maintenance has a very severe effect on transport system in the area, $24 \%$ said severe, $19 \%$ said mild, $17 \%$ said not severe and $15 \%$ said no effect. This implies that poor road maintenance affects transport system in rural areas (Figure 8). Item (e) shows that $31 \%$ of the respondents indicated that drunk driving as a major cause of road accident has a very severe effect on transport system, $11 \%$ said the effect is severe, $8 \%$ said mild, $18 \%$ said not severe and $31 \%$ said no effect. It could therefore be deduced that there is a tie between the respondents who indicated very severe effect and not affected meaning that drunk driving as a major cause of road accident has a lesser effect on transport system in rural areas (Figure 8). Item (f) reveals that 39\% of the respondents were of the view that lack of driver's experience as a major cause of road accident has a very severe effect on transport system in rural areas, $25 \%$ said severe, $14 \%$ said mild, $7 \%$ said not severe and $17 \%$ said not affected. This implies that inexperience driving often causes road accidents which affects transport system in rural areas (Figure 8).

Table 2: Causes of road accident and its effect on transport system in rural areas.

\begin{tabular}{|l|l|l|l|l|l|l|}
\hline \multirow{2}{*}{ S/N } & \multirow{2}{*}{ Causes } & \multicolumn{5}{|c|}{ Severity } \\
\cline { 3 - 7 } & & Very Severe & Severe & Mild & Not Severe & Not Affected \\
\hline a. & Bad road & $325(65 \%)$ & $15(3 \%)$ & $105(21 \%)$ & $40(8 \%)$ & $10(2 \%)$ \\
\hline b. & Over speeding & $145(29 \%)$ & $125(25 \%)$ & $115(23 \%)$ & $85(17 \%)$ & $25(5 \%)$ \\
\hline c. & Careless driving & $195(39 \%)$ & $110(22 \%)$ & $95(19 \%)$ & $45(9 \%)$ & $65(13 \%)$ \\
\hline d. & Poor road maintenance & $125(25 \%)$ & $120(24 \%)$ & $95(19 \%)$ & $85(17 \%)$ & $75(15 \%)$ \\
\hline e. & Drunk driving & $155(31 \%)$ & $55(11 \%)$ & $40(8 \%)$ & $90(18 \%)$ & $155(31 \%)$ \\
\hline f. & Lack of driver's experience & $155(39 \%)$ & $125(25 \%)$ & $70(14 \%)$ & $35(7 \%)$ & $85(17 \%)$ \\
\hline
\end{tabular}

Source: Fieldwork, 2018. 


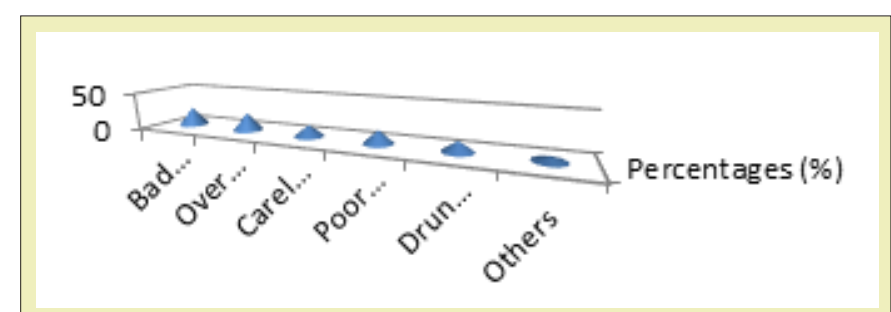

Figure 7: Causes of road accidents on urban/rural roads in the area.

Table 3 shows that, 19\% indicated that the level of development of the rural areas in the area is very high, $14 \%$ said it is high, $17 \%$ said it is moderate, $23 \%$ said it is satisfactory and $27 \%$ said it is poor. This implies that the level of development of the rural areas is poor. This indicates that the level of development of the rural areas is still at its infancy.

Table 3: Level of development of the rural areas in Ehime Mbano.

\begin{tabular}{|l|l|l|}
\hline Level & Frequency & Percentages (\%) \\
\hline Very High & 95 & 19 \\
\hline High & 70 & 14 \\
\hline Moderate & 85 & 17 \\
\hline Satisfactory & 115 & 23 \\
\hline Poor & 135 & 27 \\
\hline Total & $\mathbf{5 0 0}$ & $\mathbf{1 0 0}$ \\
\hline
\end{tabular}

Source: Fieldwork, 2018.

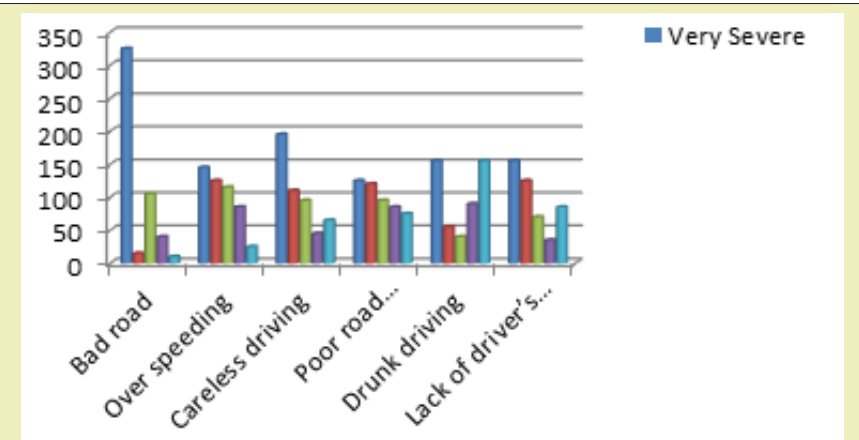

Figure 8: Causes of road accident and its effect on transport system in rural areas.

Figure 9 shows the various key role transport system played in the development of rural areas of Ehime Mbano. From the table above, Item (a) reveals that $35 \%$ of the respondents indicated that road network has played an active role in the development of rural areas, $39 \%$ said it has played a positive role, $11 \%$ said it has a played a negative role, $12 \%$ said it has played a passive role and $3 \%$ it has played no role in the development of rural areas Item (b) shows that $22 \%$ of the respondents indicated that market system have played an active role in the development of rural areas, 39\% said it has played a positive role, $19 \%$ said it has played a negative role, $19 \%$ said it has played a passive role and $11 \%$ said it has not played any role. Item (c) shows that $21 \%$ of the respondents were of the view that transport facilities have played a an active role in the development of rural areas, $36 \%$ said it has played a positive role, $12 \%$ said it has played a negative role, $19 \%$ said it has played a passive (silent) role and $12 \%$ said it has played no role. Item (d) reveals that $25 \%$ of the respondents indicated that basic infrastructure has played an active role in rural development, $24 \%$ said the role is positive, $15 \%$ said negative role, $17 \%$ said passive role and $19 \%$ said no role. This implies that the provision of basic infrastructure has played an active role in the development of rural areas of Ehime Mbano. Item (e) shows that $17 \%$ of the respondents indicated that socio-economic development has played an active role in rural development, $39 \%$ said positive role, $25 \%$ said negative role, $7 \%$ said passive role and $14 \%$ said socio-economic development has not played any role in the development of rural areas. This implies that socio-economic development has played a positive role in rural development. Item (f) reveals that $39 \%$ of the respondents were of the view that community development has played an active role in the development of rural areas, $22 \%$ said it has played a positive role, $19 \%$ said it has played a negative role, $13 \%$ said it has played a passive role and $9 \%$ said it has played no role. This implies that community development has played an active role in rural development especially in Ehime Mbano.

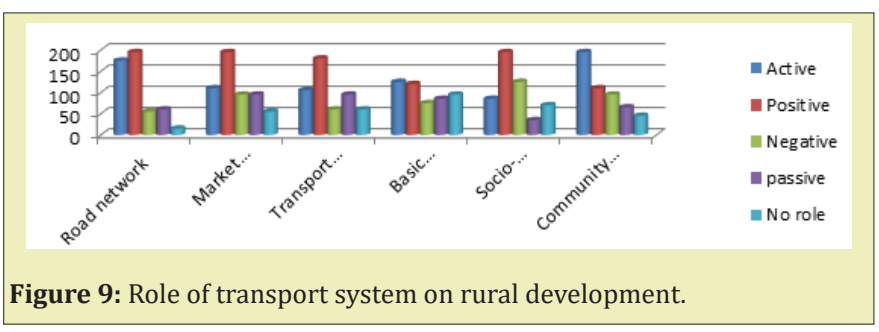

Figure 10 shows the major problems of road transport in the area. From the table above, it could be deduced that, $24 \%$ of the respondents indicated that poor road network/potholes is the major problems of road transport in the area, $17 \%$ said poor road maintenance, $5 \%$ said negligence on the part of the government, $25 \%$ said inaccessibility to roads in remote villages, $13 \%$ said lack of capital/ basic amenities to construct good roads and 15\% mentioned other problems such as insecurity from contractors, corruption, non-implementation of awarded road projects and diversion of fund meant for road construction. This implies that the road transport is faced with numerous problems which affect rural development.

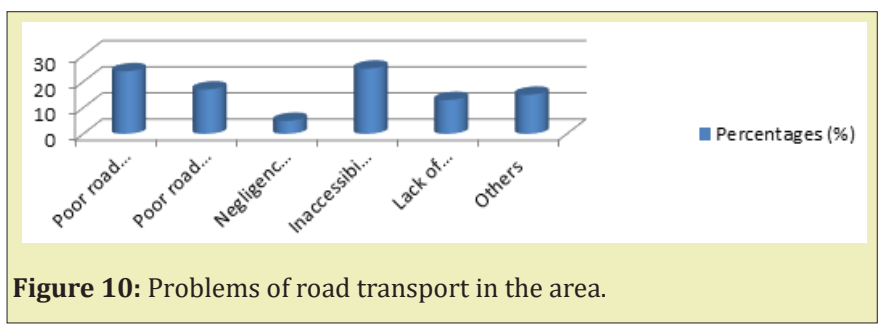

Figure 11 shows that $65 \%$ of the respondents agreed that transportation has played significant role in the development of rural areas while $35 \%$ of the respondents disagreed to this view. This 
implies that transportation has played a key role in the development of rural areas. Figure 12 shows the various sectors in which transport system impacted positively in the development of rural areas. Item (a) shows that $25 \%$ of the respondents indicated that education has a very high impact on rural development, $25 \%$ said the impact if high, $22 \%$ said moderate, $12 \%$ said is and 165 said the impact is very low. This implies that education plays a key role in the development of rural areas. Item (b) reveals that $29 \%$ of the respondents were of the view that agriculture has a very high impact on rural development, $25 \%$ said the impact if high, $23 \%$ said moderate, $17 \%$ said low and $5 \%$ said very low. This means that agriculture has played a key role in the development of rural areas (Figure 10).

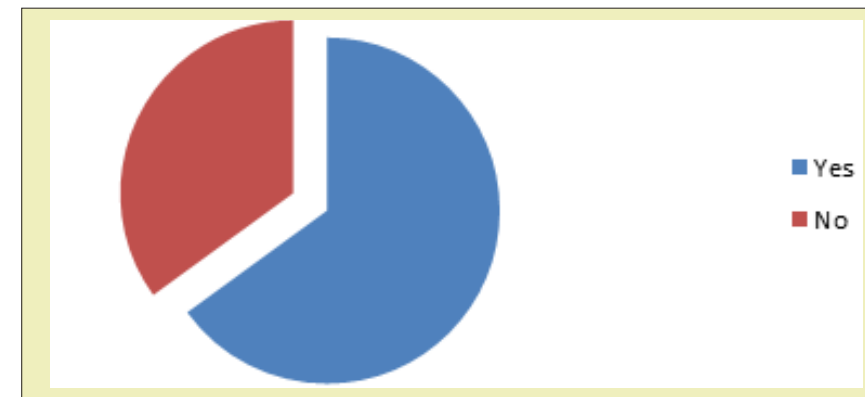

Figure 11: Significant of transportation on development of the area.

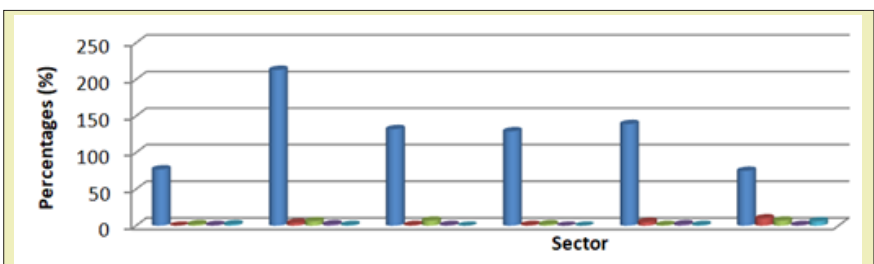

Figure 12: Positive impact of transport system on rural development.

Item (c) shows that $50 \%$ of the respondents indicated that industries have a very high impact on rural development, $17 \%$ said the impact if high, 25\% said moderate, $7 \%$ said low and $1 \%$ said very low. This implies that industries have to large extent developed rural areas (Figure 10). Item (d) shows that 345 of the respondents indicated that health care delivery has a very high impact on rural development, $28 \%$ said the impact is high, $27 \%$ said moderate impact, $8 \%$ said low and 3\% said very low. This means that health care delivery has played a key role in the development of rural areas. Item (e) reveals that $65 \%$ of the respondents indicated that commerce and trade have a very high impact on rural development, $3 \%$ said high, $8 \%$ said moderate, $21 \%$ said low and $2 \%$ said very low. This implies that commerce/trade must very large extent, developed rural areas. Item (f) shows that $24 \%$ of the respondents indicated that tourism has a very high impact on rural development, $17 \%$ said high, $19 \%$ said moderate, $24 \%$ said low and $9 \%$ said very low. This means that tourism has not played any key role in the development of rural areas. The respondents gave their reasons that most tourism potentials in rural areas have not been harnessed and developed into world class tourism sites. They furthered that government see the development of tourism sites in villages as a waste of resources/fund.

Table 4 shows that $34 \%$ of the respondents agreed that the government has played a key role in improving the transport system in rural areas while $66 \%$ of the respondents disagreed. This implies that the government has played little or no role in improving the transport system in rural areas. It said to know that government emphasis is always on urban development. The Table 5 shows the role of government in improving transport system in rural areas. From the table above, $16 \%$ of the respondents were of the view that the government has created awareness to the rural dweller through public enlightenment programs, $17 \%$ said the government has provided rural electrification, $12 \%$ said the government has improved transport facilities, $35 \%$ said the government has improved the market system, $4 \%$ said the government has linked rural-urban roads together for easy movement and $4 \%$ mentioned other roles government has played in improving transport system in the area.

Table 4: If government has played any role in improving the transport system in rural areas.

\begin{tabular}{|l|l|l|}
\hline Response & Frequency & Percentages (\%) \\
\hline Yes & 170 & 34 \\
\hline No & 330 & 66 \\
\hline Total & $\mathbf{5 0 0}$ & $\mathbf{1 0 0}$ \\
\hline
\end{tabular}

Source: Fieldwork, 2018.

Table 5: Role of government in improving the transport system in rural areas.

\begin{tabular}{|l|l|l|}
\hline Roles & Frequency & Percentages (\%) \\
\hline Public awareness & 80 & 16 \\
\hline Rural electrification & 85 & 17 \\
\hline Improved transport facilities & 120 & 24 \\
\hline Improved market system & 175 & 35 \\
\hline $\begin{array}{l}\text { Connecting rural-urban roads } \\
\text { for easy movement }\end{array}$ & 20 & 4 \\
\hline Others & 20 & 4 \\
\hline Total & $\mathbf{5 1}$ & $\mathbf{1 0 0}$ \\
\hline
\end{tabular}

Source: Fieldwork, 2018.

Table 6 shows that about $6 \%$ of the respondents were of the view that political instability and unstable government has been the major reason why the government has not played any role in improving transportation network in rural areas, $21 \%$ said reason due to inaccessibility of remote villages, $5 \%$ said because of poor communication, $31 \%$ said because of lack of community effort, $34 \%$ said reason due to lack of commitment on the part of the government and $2 \%$ said mentioned others reasons mentioned why they feel government has not played any role in improving transportation network in rural areas.

Figure 13 shows the level of development in the rural areas because of good road network. Item (a) reveals that $5 \%$ of the re- 
spondents were of the view that rural electrification in rural areas of Ehime Mbano is in a very good state, $17 \%$ said good, $25 \%$ said satisfactory, $23 \%$ said poor and $29 \%$ said very poor. This implies that the level of rural development in terms of electricity and power supply is very poor. Item (b) shows that $3 \%$ of the respondents indicated that transport system in rural areas is very good, $8 \%$ said good, $65 \%$ said satisfactory, $21 \%$ said poor and $2 \%$ said very poor. This implies that the provision of transport services in rural areas is to a large extent satisfactory. Item (c) shows that the level of rural development in terms of drainage system is very poor. This is because majority of the respondents attested to this claim. About $21 \%$ said very good, $17 \%$ said good, $16 \%$ satisfactory, $35 \%$ said poor and $12 \%$ said very poor. This means that there is inadequate and poor drainage system in rural areas of Ehime Mbano. Item (d) shows that $19 \%$ of the respondents were of the view communication system in rural areas is very good, $8 \%$ said good, $15 \%$ said satisfactory, $18 \%$ said poor and $39 \%$ said very poor. This implies that there is poor communication system in rural areas of Ehime Mbano. Item (e) shows that $25 \%$ of the respondents in rural areas indicated that trade/industry is in a very good state, $7 \%$ said good, $50 \%$ said the provision of commercial and industrial services is satisfactory, $1 \%$ said poor and $17 \%$ said very poor. This implies that the level of rural development in terms of trade and industry is satisfactory. Item (f) shows that the level of rural development in terms of tourism and recreation is very good. This is because majority of the respondents supported this view. About $16 \%$ of the respondents said very good, 355 said good, $17 \%$ said satisfactory, $21 \%$ said poor and $12 \%$ said very poor. Item (g) shows that the level of rural development in terms of agriculture and commerce is very good. This is because majority of the respondents supported this view. About $27 \%$ said very good, $14 \%$ said good, $17 \%$ said the level of rural development is satisfactory, $23 \%$ said poor and $19 \%$ said very poor. The inhabitants reveal that $39 \%$ of the respondents were of the view that poor road network as the major mode of transportation affect the source of livelihood of the inhabitants in the study area, $19 \%$ said it has affected their occupation, 19\% said it has affected their source of income, $3 \%$ said it has increased the crime rate in the area, 9\% said it has affected government policy and 11\% mentioned other ways through which poor road network as the major mode of transportation affects the inhabitants in Ehime Mbano L.G.A of Imo State. Also the work reveals that $15 \%$ of the respondents suggested that the government/private individuals should provide good road infrastructure in rural areas, $20 \%$ suggested that government should provide good road network and there should regular maintenance of existing road networks, $7 \%$ of the respondents suggested government should provide speed limit to regulate over speeding and prevent frequent road accident, 6\% suggested that government should employ experienced and qualified drivers in the case of government owned transportation companies, $43 \%$ suggested that government should improve the transport system,
$3 \%$ suggested that there should be improved traffic system to regulate driving speed especially when crossing busy roads, 5\% suggested that government should established other transport unions other National Union of Road Transport Workers (NUTRW) and 1\% suggested other ways to solve transportation problems.

Table 6: Reasons why the respondents feel the government has not played any role.

\begin{tabular}{|l|l|l|}
\hline Reasons & Frequency & Percentages (\%) \\
\hline Political instability & 30 & 6 \\
\hline Inaccessibility of remote villages & 105 & 21 \\
\hline Poor communication network & 25 & 5 \\
\hline Lack of community effort & 155 & 31 \\
\hline $\begin{array}{l}\text { Lack of commitment on the part } \\
\text { of the government }\end{array}$ & 170 & 34 \\
\hline Others & 10 & 2 \\
\hline Total & $\mathbf{5 0 0}$ & $\mathbf{1 0 0}$ \\
\hline
\end{tabular}

Source: Fieldwork, 2018.

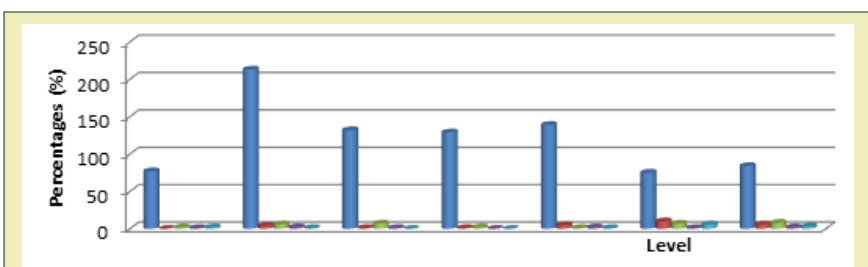

Figure 13: Positive impact of transport system on rural development.

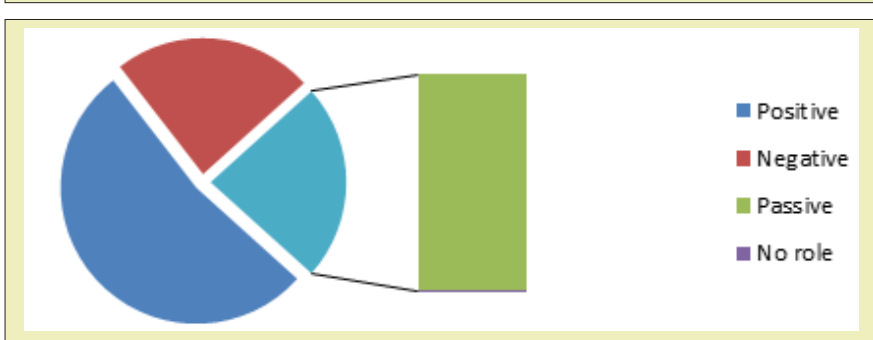

Figure 14: Impact of transport system on rural development.

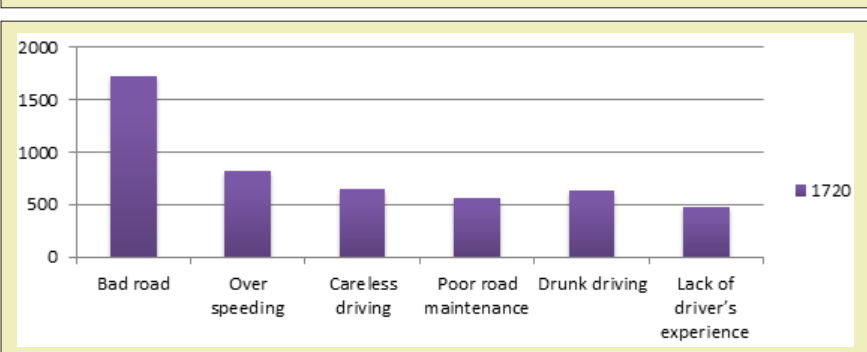

Figure 15: Problems of Transport system in rural areas.

\section{Testing of hypothesis}

The hypothesis earlier formulated were tested below using the Chi-Square $\left(\mathrm{X}^{2}\right)$ statistical technique.

\section{Hypothesis one}

$\mathbf{H}_{\mathbf{0}} \quad$ Transport system has no significant impact on rural development in Ehime Mbano Local Government Area of Imo State. 
$\mathbf{H}_{1}$. Transport system has a significant impact on rural development in Ehime Mbano Local Government Area of Imo State (Tables 7-9).

\section{Research result}

$\mathrm{X}^{2}$ calculated value $=51.501$

$\mathrm{X}^{2}$ critical value $=31.410$

Accept $H_{1}$ and reject $H_{0}$ since $X^{2}$ calculated value (51.501) is greater than $\mathrm{X}^{2}$ critical table value of 31.410 (see appendix). Transport system has significant impact on rural development in Ehime Mbano Local Government Area of Imo State.

\section{Hypothesis two}

$\mathbf{H}_{\mathbf{0}}$ Transport system has not played any significant role in the development in Ehime Mbano Local Government Area of Imo State.

$\mathbf{H}_{1:}$ Transport system has not played any significant role in the development in Ehime Mbano Local Government Area of Imo State.

See Tables $10 \& 11$

$\mathrm{X}^{2}$ calculated value $=36.306$

$\mathrm{X}^{2}$ critical value $=31.410$

Table 7: Impact of transport system on rural development.

\begin{tabular}{|l|l|l|l|l|l|l|l|l|l|l|l|}
\hline S/N & Sectors & Very High & $\mathbf{\%}$ & High & $\mathbf{9}$ & Moderate & $\mathbf{\%}$ & Low & $\mathbf{\%}$ & Very low & \% \\
\hline a. & Education & 125 & 25 & 125 & 25 & 110 & 22 & 60 & 12 & 80 & 16 \\
\hline b. & Agriculture & 145 & 29 & 125 & 25 & 115 & 23 & 85 & 17 & 25 & 5 \\
\hline c. & Industries & 250 & 50 & 85 & 17 & 125 & 25 & 85 & 17 & 5 & 1 \\
\hline d. & Health care delivery & 170 & 34 & 140 & 28 & 135 & 27 & 40 & 8 & 15 & 3 \\
\hline e. & Commerce/trade & 325 & 65 & 15 & 3 & 40 & 8 & 105 & 21 & 10 & 2 \\
\hline f. & Tourism & 180 & 36 & 85 & 17 & 95 & 19 & 120 & 24 & 95 & 19 \\
\hline
\end{tabular}

Table 8: Impact of transport system on rural development 2.

\begin{tabular}{|l|l|l|l|l|l|l|}
\hline S/N & Very High & High & Moderate & Low & Very low & Total \\
\hline a. & 125 & 125 & 110 & 60 & 80 & 500 \\
\hline b. & 145 & 125 & 115 & 85 & 25 & 500 \\
\hline c. & 250 & 85 & 125 & 85 & 5 & 500 \\
\hline d. & 170 & 140 & 135 & 40 & 15 & 500 \\
\hline e. & 325 & 15 & 40 & 105 & 95 & 500 \\
\hline f. & 180 & 85 & 95 & 120 & 95 & 500 \\
\hline Total & $\mathbf{1 1 9 5}$ & $\mathbf{5 7 5}$ & $\mathbf{6 2 0}$ & $\mathbf{4 9 5}$ & $\mathbf{3 1 5}$ & $\mathbf{3 0 0 0}$ \\
\hline
\end{tabular}

Table 9: Chi-Square Analysis.

\begin{tabular}{|l|l|l|l|l|l|}
\hline Model & $\mathbf{- 2}$ Log Likelihood & Chi-Square & df & Sig. & Decision \\
\hline Intercept Only & 51.501 & & & & Reject $\mathrm{H}_{0}$ \\
\hline Final & 0 & 51.501 & 20 & 0.001 & \\
\hline
\end{tabular}

Source: Author's Research, 2018.

Table 10: The role of transport system on rural development.

\begin{tabular}{|l|l|l|l|l|l|l|l|l|l|l|l|}
\hline S/N & Option & Active & $\mathbf{\%}$ & Positive & $\mathbf{\%}$ & Negative & \% & Passive & \% & No role & \% \\
\hline a. & Road network & 175 & 35 & 195 & 39 & 55 & 11 & 60 & 12 & 15 & 3 \\
\hline b. & Market system & 110 & 22 & 195 & 39 & 95 & 19 & 95 & 19 & 55 & 11 \\
\hline c. & Transport facilities & 105 & 21 & 180 & 36 & 60 & 12 & 95 & 19 & 60 & 12 \\
\hline d. & Basic infrastructure & 125 & 25 & 120 & 24 & 75 & 15 & 85 & 17 & 95 & 19 \\
\hline e. & Socio-economic development & 85 & 17 & 195 & 39 & 125 & 25 & 35 & 7 & 70 & 14 \\
\hline f. & Community development & 295 & 39 & 110 & 22 & 95 & 19 & 65 & 13 & 45 & 9 \\
\hline
\end{tabular}

Table 11: Chi square analysis on decision.

\begin{tabular}{|l|l|l|l|l|l|}
\hline Model & $\mathbf{- 2}$ Log Likelihood & Chi-Square & df & Sig. & Decision \\
\hline Intercept Only & 17.918 & & & & Reject $\mathrm{H}_{0}$ \\
\hline Final & 11.612 & 36.306 & 20 & 0.098 & \\
\hline
\end{tabular}

Source: Author's Research, 2018.

Accept $H_{1}$ and reject $H_{0}$ since $X^{2}$ calculated value (36.306) is greater than $\mathrm{X}^{2}$ critical table value of 31.410 (see appendix). Trans- port system has played significant role in the development in Ehime Mbano Local Government Area of Imo State 


\section{Hypothesis three}

$\mathrm{H}_{0}$ : There is no significant relationship between the causes of road accident on urban/rural road and the problems of transportation Ehime Mbano Local Government Area of Imo State.

$\mathrm{H}_{1}$ : There is a significant relationship between the causes of road accident on urban/rural road and the problems of transportation Ehime Mbano Local Government Area of Imo State.
See Table 12.

$\mathrm{X}^{2}$ calculated value $=55.910$

$\mathrm{X}^{2}$ critical value $=31.410$

Accept $H_{1}$ and reject $H_{0}$ since $X^{2}$ calculated value (55.910) is greater than $\mathrm{X}^{2}$ critical table value of 31.410 (see appendix). There is a significant relationship between the causes of road accident on urban/rural road and the problems of transportation Ehime Mbano Local Government Area of Imo State.

Table 12: Chi-Square Analysis on decision 2.

\begin{tabular}{|l|l|l|l|l|}
\hline Model & $\mathbf{- 2}$ Log Likelihood & Chi-Square & df & Sig. \\
\hline Intercept Only & 55.910 & & & Decision \\
\hline Final & 11.612 & 55.910 & 20 & 0.098 \\
\hline
\end{tabular}

\section{Discussion of Result/Findings}

From the analysis obtained in hypothesis one, the $\mathrm{X}^{2}$ calculated value of 51.501 is greater than the critical table value of 31.410 at 0.05 level of confidence. The model is also significant at 0.05 level of significant indicating that the independent variable (transport system) has greater impact on the dependent variable (rural development). Therefore, $\mathrm{H}_{0}$ is rejected and $\mathrm{H}_{1}$ is accepted. Hence, transport system has significant impact on rural development in Ehime Mbano Local Government Area of Imo State. It could also be deduced that rural development depends on effective transport system and infrastructural development. From the analysis obtained in hypothesis two, the $\mathrm{X}^{2}$ calculated value of 36.306 is greater than the critical table value of 31.410 . Hence, the null hypothesis which states that transport system has not played any significant role in the development in Ehime Mbano Local Government Area of Imo State is rejected and the alternative hypothesis which states that transport system has played significant role in the development in Ehime Mbano Local Government Area of Imo State is accepted. The role of transportation on rural development cannot be overlooked. Transport system have played active role in the development of rural areas and have improved the socio-economic life of the inhabitants of the rural dwellers. From the analysis obtained in hypothesis three, the $\mathrm{X}^{2}$ calculated value of 55.910 is greater than the critical table value of 31.410 at 0.05 level of confidence. Therefore, $\mathrm{H}_{0}$ is rejected meaning that the null hypothesis which states that there is no significant relationship between the causes of road accident on urban/ rural road and the problems of transport system in Ehime Mbano Local Government Area of Imo State is rejected and $\mathrm{H}_{1}$ is accepted meaning that the alternative hypothesis which states that there is a significant relationship between the causes of road accident on urban/rural road and the problems of transport system in Ehime Mbano Local Government Area of Imo State is accepted. It could be deduced that there is a positive correlation between the causes of road accident on urban/rural road and the problems of transport system in Ehime Mbano Local Government Area of Imo State since the model is significant at 0.05 level of significance.

\section{Summary of Findings, Conclusion and Recommenda- tions}

\section{Summary of findings}

This study was conducted to examine the role of transport system in rural development in Ehime Mbano L.G.A of Imo State. It has been observed that untarred/seasonal roads and foot track dominates in the study area. Lack of good roads in the study area has great negative impacts on the socio-economic activities of the rural communities. Studies has shown that improvement in transport system by given priority in road development will no doubt enhance the socio-economic activities of the study area thereby improving the well-being of the people in the area. The reviewed literature showed that transport system has been faced with numerous problems due to poor road maintenance and bad road, lack of fund to construct good roads, poor road network. Government has been reluctant to road construction and community development. As a result of this, remote villages have become inaccessible especially during the rainy season. Though efforts have been made to address problems of transport system, but all efforts made so far have proved abortive as the situation keep on worsen day by day. While gathering relevant information for this study, data were collected from two main sources: primary and secondary sources. The data obtained from the administration of questionnaire were analyzed. The use of tables, bar graphs and percentages formed the preliminary analysis for this study while the hypothesis formulated were tested using the Chi-Square method. The results of the findings indicated that transport system has a significant impact on rural development in Ehime Mbano Local Government Area of Imo State. The findings also reveal that transport system has played significant role in the development of Ehime Mbano Local Government Area of Imo State. The findings reveal that there is a significant rela- 
tionship between the causes of road accident on urban/rural road and the problems of transport system in Ehime Mbano Local Government Area of Imo State.

\section{Conclusion}

The study concluded that transport system has a significant impact on rural development in Ehime Mbano Local Government Area of Imo State since the $\mathrm{X}^{2}$ calculated value (51.501) is greater than the critical table value (31.410) at 0.05 level of confidence. The conclusion was also since the model is significant at 0.05 level of significance indicating that the independent variable (transport system) has a greater impact on the dependent variable (rural development).The study concluded that transport system has played significant role in the development of Ehime Mbano Local Government Area of Imo State since the $\mathrm{X}^{2}$ calculated value (36.306) is greater than the critical table value (31.410). The conclusion was also based on the fact that the model is significant at 0.05 level of significance indicating that transport system has played active role in the development of rural areas and have improved the socio-economic life of the inhabitants of the rural dwellers. Finally, the study established the fact that that there is a significant relationship between the causes of road accident on urban/rural road and the problems of transport system in Ehime Mbano Local Government Area of Imo State since the $\mathrm{X}^{2}$ calculated value (55.910) is greater than the critical table value (31.410) at 0.05 level of confidence. The conclusion is also based on the fact that there is a positive correlation between the causes of road accident on urban/rural road and the problems of transport system in Ehime Mbano Local Government Area of Imo State since the model is significant at 0.05 level of significance.

\section{Recommendations}

The researcher recommended the following based on the findings obtained from the study; The government and private organizations should organize public awareness programs on the dangers of inexperience driving alongside the positive role of transport system on rural development. The government/private individuals should provide good road network, basic infrastructure such as rural electrification and power supply to the rural populace. Government should embark on maintenance and rehabilitation of existing roads. The government should provide speed limit to regulate over speeding and prevent frequent road accident. The government should employ experienced and qualified drivers in the case of government owned transport companies. The government should improve the transport system through the provision of basic amenities and community services. There should be improved traffic system to regulate driving speed especially when crossing busy roads. Finally, the government should establish other transport unions other National Union of Road Transport Workers (NUTRW) to monitor road users and commuters especially when plying the rural roads and terminal points.

\section{Acknowledgements}

None.

\section{Conflicts of Interest}

Author declares that there is no conflict of interest.

\section{Funding}

None.

\section{References}

1. Olawole MO, Aloba, Adetunji MA. The place of transport in the attainment of Millennium development goals in rural areas of Nigeria. Ife Journal of Environmental Design and Management. 2010;4(1):33-48.

2. Asian Development Bank. When do Rural Roads benefit the Poor and How? An In-depth Analysis Based on Case Studies. Asian Development Bank. 2006.

3. Beenhakker HL. Rural Transport Services. A Guide to their Planning and Implementation. London: Intermediate Technology Publications. 2007.

4. Okoko F. The Demand for Para-Transit Transport Services in Nigerian Towns. The case of Motorcycles Transport in Akure. Journal of Transport Studies. 1998;2(1):9-11.

5. Mabogunje AL. The Development Process: A Spatial Perspective. London: Hutchinson and Ltd. 1980.

6. Okoko E. Rural Transportation and Rural Development. The Instance of Akwapim south District in Ghana. Department of Transport Management Technology, School of Management Technology. Federal University of Technology, Printing Press, Akure, Ondo state, Nigeria. International Journal of Economic Development Research and Investment. 2011;2(3):10-26.

7. Aweto A. Outline Geography of Urho Boland. Urhobo Historical Society. University of Ibadan Press. 2002;8-13.

8. Coombs PH, Ahmed M. Attacking Rural Poverty. Baltimore: John Hopkins University Press. 2014.

9. Ahmed R, Hossain A. Development Impact of Rural Infrastructure in Bangladesh. Washington, D.C; International Food Policy Research Institute. 1990.

10. Asagba JO. The untold story of a Nigerian royal family. The Urhobo Ruling Clan of Ehime Mbano Kingdom Universe Inc. 2005.

11. Atubi AO, Onokala PC. Road Transportation and the Socio-economic Development of the Niger Imo. A case study of Warri Metropolis. Journal of Social and Management Sciences Review. 2004;1:102-113.

12. Atubi AO. The Effectiveness of Para-Transit Transport Services in Owerri Region. In: Akinbode A, editor. Owerri Region, Published by the Department of Geography \& Regional Planning Delsu, Owerri. Printed by Central Book Ltd. 2006.

13. Dakyes SP, Ogbuli LN. The Impact of Transportation on the socioeconomic Development of Rural Areas of Gwagwalada Area Council, Nigeria. Confluence Journal Environmental Studies (CJES). 2012;7:112-117.

14. Brown CK. Rural Development in Ghana Accra Ghana University Press. 2016.

15. Adeniji K. Factors of Rural Transport (Demand and Supply). The Ogun State Experience. In Faniran, A. editor, Rural Development in Ogun State, Nigeria. Department of Geography and Environmental Management, Ogun State University Publication. 2007;181-193.

16. Atubi AO, Onokala PC. The accessibility of Centres of the Road Networks. A case study of Lagos Island, Lagos. International Journal of Economy and Environment dynamics. 2004;2:140-151. 